\title{
In vitro screening antiviral activity of Thai medicinal plants against porcine reproductive and respiratory syndrome virus
}

Chaiwat Arjin ${ }^{1}$, Kidsadagon Pringproa ${ }^{2,3}$, Surat Hongsibsong ${ }^{3,4}$, Warintorn Ruksiriwanich ${ }^{3,5}$, Mintra Seel-audom? , Supamit Mekchay ${ }^{1,3}$ and Korawan Sringarm ${ }^{1,3^{*}}$

\begin{abstract}
Background: Porcine reproductive and respiratory syndrome (PRRS) caused by PRRS virus (PRRSV) results in economic losses in the swine industry globally. Several studies have investigated the use of plant extracts in the prevention and control of PRRS outbreaks. Thai medicinal plants may be useful for treating PRRSV infection in pigs. Therefore, we investigated the in vitro anti-PRRSV and antioxidant properties of seven Thai medicinal plants: Caesalpinia sappan Linn., Garcinia mangostana Linn., Houttuynia cordata, Perilla frutescens, Clinacanthus nutans, Phyllanthus emblica, and Tiliacora triandra.

Results: Using antiviral screening, we observed that T. triandra extract strongly inhibited PRRSV infectivity in MARC145 cells [virus titer 3.5 median tissue culture infective dose $\left(T_{C I D}\right) / \mathrm{ml}(\log 10)$ ] at $24 \mathrm{~h}$ post-infection, whereas $C$. sappan extract strongly inhibited PRRSV replication [virus titer $2.5 \mathrm{TCID} 5 \mathrm{O} / \mathrm{ml}(\log 10)]$ at $72 \mathrm{~h}$ post-infection. C. sappan extract had the highest total phenolic content [220.52 mM gallic acid equivalent/g] and lowest half-maximal inhibitory concentration $[1.17 \mathrm{mg} / \mathrm{ml}$ in 2,2-diphenyl-1-picrylhydrazyl and $2.58 \mathrm{mg} / \mathrm{ml}$ in 2,2-azino-bis (3ethylbenzothiazo-line-6-sulfonic acid) diammonium salt].

Conclusion: T. triandra extract could inhibit PRRSV infectivity, whereas C. sappan extract was the most effective in inhibiting PRRSV replication in MARC-145 cells. This study elucidates the antiviral activities of Thai medicinal plant extracts in vivo. The results promise that Thai medicinal plant extracts, particularly T. triandra and C. sappan extracts, can be developed into pharmaceutical drugs for the prevention of PRRS in pigs.
\end{abstract}

Keywords: Porcine reproductive and respiratory syndrome, Porcine reproductive and respiratory syndrome virus, Antiviral activity, Thai medicinal plants

\footnotetext{
*Correspondence: kanok70@hotmail.com

'Department of Animal and Aquatic Sciences, Faculty of Agriculture, Chiang

Mai University, 239, Huaykaew Road, Suthep, Muang, Chiang Mai 50200,

Thailand

${ }^{3}$ Cluster of Research and Development of Pharmaceutical and Natural

Products Innovation for Human or Animal, Chiang Mai University, Chiang Mai 50200, Thailand

Full list of author information is available at the end of the article
}

(c) The Author(s). 2020 Open Access This article is licensed under a Creative Commons Attribution 4.0 International License, which permits use, sharing, adaptation, distribution and reproduction in any medium or format, as long as you give appropriate credit to the original author(s) and the source, provide a link to the Creative Commons licence, and indicate if changes were made. The images or other third party material in this article are included in the article's Creative Commons licence, unless indicated otherwise in a credit line to the material. If material is not included in the article's Creative Commons licence and your intended use is not permitted by statutory regulation or exceeds the permitted use, you will need to obtain permission directly from the copyright holder. To view a copy of this licence, visit http://creativecommons.org/licenses/by/4.0/ The Creative Commons Public Domain Dedication waiver (http://creativecommons.org/publicdomain/zero/1.0/) applies to the data made available in this article, unless otherwise stated in a credit line to the data. 


\section{Background}

Porcine reproductive and respiratory syndrome virus (PRRSV) is endemic in most pig-producing countries, and it results in enormous economic losses to the swine industry globally [1]. This enveloped, positive-sense, singlestranded RNA virus belongs to the Arteriviridae family (order Nidovirales), which also includes the equine arteritis virus, mouse lactate dehydrogenase-elevating virus, and simian hemorrhagic fever virus [2]. In general, PRRSV infection causes a disease that is characterized by reproductive failure in sows and respiratory infections in growing pigs [3], and this disease predisposes pigs to infection by bacteria and other viral pathogens $[4,5]$. This disease is known as porcine reproductive and respiratory syndrome (PRRS) and has become endemic in many countries throughout the world following an epidemic phase $[6,7]$. Its incidence was first reported in Thailand in 1989, and since then, several outbreaks have been reported [8]. It has become a major infectious disease that causes high mortality in swine and production losses in the swine industry in this country.

Preventative measures such as gilt acclimatization, vigilant biosecurity, and vaccination have been shown to be useful in controlling PRRS outbreaks, and supportive treatments are available for alleviating its severity; however, no specific treatment for PRRS is available $[9,10]$. Antiviral therapeutics are a critical tool for combating viral infections, particularly in cases wherein no vaccines are available against the circulating virus. Thus, pharmacological intervention may represent an alternative approach in controlling PRRSV. A number of natural compounds and compositions have been shown to possess antiviral activities against PRRSV. Gao et al. [11] showed that Cryptoporus volvatus extract exhibited antiviral activity against PRRSV infection and replication. Pringproa et al. [12] reported that crude Cynodon dactylon extract significantly inhibited PRRSV replication as early as $24 \mathrm{~h}$ post-infection (hpi). Therefore, the antiviral activities of other Thai medicinal plants against PRRSV should also be investigated. Thai medicinal plants such as Caesalpinia sappan Linn., Garcinia mangostana Linn., Houttuynia cordata, Perilla frutescens, Clinacanthus nutans, Phyllanthus emblica, and Tiliacora triandra are known to have antioxidant and antiviral activities. These plants have already been promoted for use in primary health care and have been classified according to their pharmacological actions [13-18]. Therefore, the aim of this study was to determine the antiviral activities of Thai medicinal plant extracts against PRRSV infection in vitro and to measure their phytochemical contents to develop an alternative anti-PRRSV therapy for use in veterinary medicine.

\section{Results}

Cytotoxic activities of plant extracts

Prior to determining antiviral activity, we evaluated the cytotoxicity of the seven Thai medicinal plant extracts on the viability of MARC-145 cells, and viability is expressed as $50 \%$ cytotoxic concentration $\left(\mathrm{CC}_{50}\right)$. The results showed that the $\mathrm{CC}_{50}$ of the seven plant extracts ranged from 78 to $2500 \mu \mathrm{g} / \mathrm{ml}$, and the effect of Thai medicinal plant extract concentration on the tested cells increased in a dose-dependent manner (Fig. 1). $P$. emblica extract had the lowest $\mathrm{CC}_{50}$ of $78 \mu \mathrm{g} / \mathrm{ml}$. The $\mathrm{CC}_{50}$ of $\mathrm{G}$. mangostana extract was the second lowest $(312.5 \mu \mathrm{g} / \mathrm{ml})$ and that of C. sappan extract was $625 \mu \mathrm{g} /$ ml. Further, T. triandra and $H$. cordata extracts had $\mathrm{CC}_{50}$ of $1250 \mu \mathrm{g} / \mathrm{ml}$, whereas C. nutans and P. frutescens extracts had the highest $\mathrm{CC}_{50}(2500 \mu \mathrm{g} / \mathrm{ml})$.

\section{Inhibition of PRRSSV infection by Thai medicinal plant extracts}

We treated PRRSV with different concentrations of Thai medicinal plant extracts that were determined based on their $\mathrm{CC}_{50}$ values so that these plant extracts did not affect the proliferative activity of MARC-145 cells. The screening results of the inhibition of PRRSV infectivity showed the potential of Thai medicinal plant extracts to inhibit PRRSV infectivity (Fig. 2). T. triandra extract significantly inhibited PRRSV infectivity in MARC-145 cells at $24 \mathrm{hpi}$ when supplied at a concentration of $1250 \mu \mathrm{g} /$ $\mathrm{ml}(P<0.05)$, and the observed virus titer at this concentration was $3.5 \mathrm{TCID}_{50} / \mathrm{ml}\left(\log _{10}\right)$. Interestingly, $P$. emblica extract at a low concentration of $78 \mu \mathrm{g} / \mathrm{ml}$ could inhibit PRRSV infectivity [virus titer $=4.5 \mathrm{TCID}_{50} / \mathrm{ml}$ $\left.\left(\log _{10}\right)\right]$. As shown in Fig. 3, immunoperoxidase monolayer assay (IPMA) indicated that $T$. triandra and $P$. emblica extracts blocked PRRSV infectivity in MARC145 cells, as shown by slight brown staining of cells.

\section{Thai medicinal plant extracts inhibit PRRSV replication}

Different Thai medicinal plant extracts were tested in an in vitro inhibitor screening assay to determine inhibition of PRRSV replication at three time intervals $(24,48$, and $72 \mathrm{hpi})$. At various time points after the infection, PRRSV in supernatants was quantified for determining virus titer by IPMA. Results of screening were the same as those of the inhibition test of PRRSV infectivity, i.e., PRRSV replication was inhibited in a dose-dependent manner (Fig. 4). Interestingly, as shown in Fig. 5, we found that $C$. sappan extract had significant potential to inhibit PRRSV replication in vitro. As shown in Fig. 5L, few cells that were stained brown showed the efficiency of C. sappan extract at a concentration of $625 \mu \mathrm{g} / \mathrm{ml}$, and the inhibition of PRRSV replication by $C$. sappan extract was significantly stronger than that by other plant extracts at $72 \mathrm{hpi}\left[2.7 \mathrm{TCID}_{50} / \mathrm{ml}\left(\log _{10}\right)\right]$.

Phytochemical contents of Thai medicinal plant extracts The total phenolic contents of the seven Thai medicinal plant extracts were determined using the Folin-Ciocalteu 


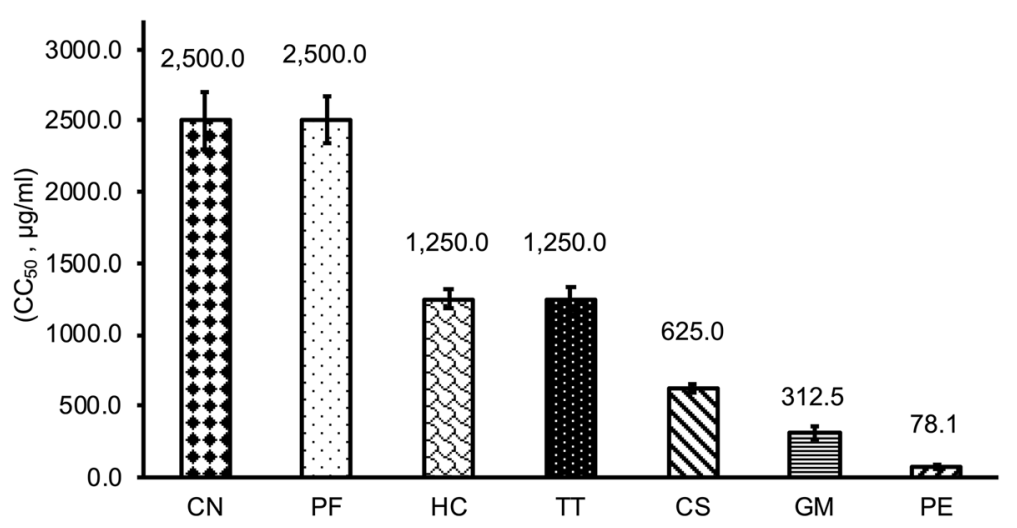

Fig. 1 Cytotoxity of the seven Thai medicinal plant extracts on MARC-145 cells determined by the 3-(4,5-dimethylthiazol-2-yl)-2,5-diphenyl tetrazolium bromide (MTT) assay. MARC-145 cells were incubated with various concentrations of these plant extracts or control without plant extract for $72 \mathrm{~h}$ prior to the MTT assay. Values are expressed as mean \pm standard error. CN, Clinacanthus nutans; PF, Perilla frutescens; HC, Houttuynia cordata; TT, Tiliacora triandra; CS, Caesalpinia sappan Linn.; GM, Garcinia mangostana Linn.; PE, Phyllanthus emblica; $C_{50}, 50 \%$ cytotoxic concentration

assay by constructing a standard curve of gallic acid. Total phenolic content was the highest in C. sappan extract [mean \pm standard error: $220.52 \pm 4.47 \mathrm{mM}$ gallic acid equivalent (GAE)/g sample], followed by G. mangostana extract (91.16 $\pm 4.62 \mathrm{mM} \mathrm{GAE} / \mathrm{g}$ sample), with the lowest total phenolic content was observed in $H$. cordata extract (8.51 $\pm 0.04 \mathrm{mM} \mathrm{GAE/g} \mathrm{sample)} \mathrm{(Table} 1)$.

\section{Antioxidant activity}

C. sappan extract had the highest antioxidant activity, with $\mathrm{IC}_{50}$ values of $1.17 \pm 0.06 \mathrm{mg} / \mathrm{ml}$ in 2,2-diphenyl-1picrylhydrazyl (DPPH) and $2.57 \pm 0.16 \mathrm{mg} / \mathrm{ml} \mathrm{n} \mathrm{2,2-}$ azino-bis(3-ethylbenzothiazo-line-6-sulfonic acid) diammonium salt (ABTS) and a reducing power of $334.78 \pm 13.15 \mathrm{mM} \mathrm{Fe}^{2+} / \mathrm{g}$ in the ferric-reducing antioxidant power (FRAP) assay (Table 1). P. emblica extract had the second strongest antioxidant activity against free radicals, with $\mathrm{IC}_{50}$ values of $3.49 \pm 0.17 \mathrm{mg} / \mathrm{ml}$ in $\mathrm{DPPH}$ and $4.95 \pm 0.11 \mathrm{mg} / \mathrm{ml}$ in ABTS and a reducing power of $94.17 \pm 0.62 \mathrm{mM} \mathrm{Fe}^{2+} / \mathrm{g}$ sample in the FRAP assay.

\section{Discussion}

PRRSV outbreak causes significant economic loss in the swine industry worldwide. The current commercial PRRSV vaccines are inadequate to protect pigs from PRRSV infections [19]. Medicinal plants have progressively been explored as suitable alternative sources of antiviral agents [20]. Thai medicinal plants have widely been used as a source of herbal medicines because of their high bioactive compound contents that are effective against various diseases. In this study, seven Thai medicinal plant extracts were screened for their antiviral activity against PRRSV.

Before determining the antiviral properties of a compound, it is essential that a cytotoxicity assay is performed to determine the concentrations that can be used to avoid cell damage and ensure PRRSV selectivity in vitro. In this study, we reported cytotoxicity as $\mathrm{CC}_{50}$, which indicates the concentration of a substance that can inhibit virus activity by $50 \%$. We found that $P$. emblica extract showed the highest cell toxicity $(78.1 \mu \mathrm{g} / \mathrm{ml})$. In this study, high-potential plant extracts were found to be C. sappan and T. triandra extracts, with $\mathrm{CC}_{50}$ of 625 and $1250 \mu \mathrm{g} / \mathrm{ml}$, respectively. Antiviral compounds should be highly effective while showing minimal toxicity to normal cells and tissues [21].

In this study, we investigated the antiviral activity of seven Thai medicinal plant extracts against PRRSV by assessing the inhibition of PRRSV infection and replication in MARC-145 cells. The range of plant extract concentrations was determined based on their $\mathrm{CC}_{50}$ values. P. emblica extract inhibited PRRSV infection in MARC145 cells and in vitro. P. emblica extract at a concentration of $78 \mu \mathrm{g} / \mathrm{ml}$ inhibited PRRSV infectivity at a virus titer of $4.5 \mathrm{TCID}_{50} / \mathrm{ml}\left(\log _{10}\right)$. In this study, P. emblica extract showed the highest cytotoxicity to MARC-145 cells with $\mathrm{CC}_{50}$ of $<100 \mu \mathrm{g} / \mathrm{ml}$. Therefore, the antiviral activity of other plant extracts were investigated in this study. We found that $T$. triandra extract at a concentration of $1250 \mu \mathrm{g} / \mathrm{ml}$ significantly inhibited PRRSV infectivity at a virus titer of $3.5 \mathrm{TCID}_{50}(\log 10)$. While $T$. triandra extract has been used as anti-inflammatory [22], anticancer [23], and antimicrobial agents against Mycobacterium tuberculosis [24], its antiviral activity, particularly against PRRSV, has not been investigated previously. Therefore, this is the first report to indicate that $T$. triandra extract could significantly prevent the entry of PRRSV into MARC-145 cells. However, T. triandra extract was not found to be effective in inhibiting PRRSV replication. All studied plant extracts could inhibit PRRSV replication when applied at high 


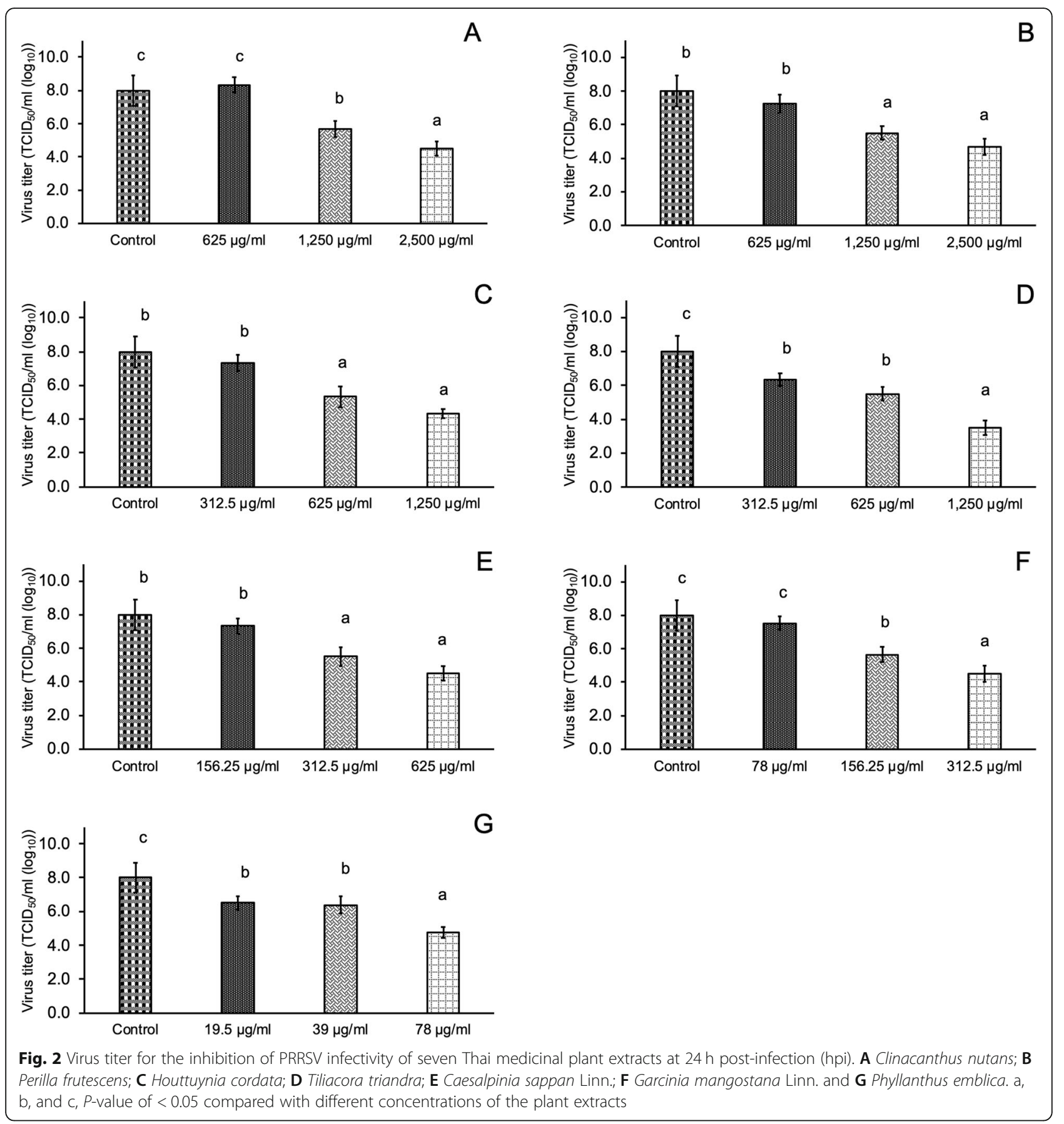

concentrations, as shown by the linear regression model from 24 to $72 \mathrm{hpi}$ after incubation with PRRSV. C. sappan extract at a concentration of $625 \mu \mathrm{g} / \mathrm{ml}$ could inhibit PRRSV replication as $72 \mathrm{hpi}$ [virus titer $2.7 \mathrm{TCID}_{50}$ $(\log 10)]$. Although the antiviral activity of $C$. sappan extract against the influenza virus [13] and the antimicrobial properties of C. sappan [25] have previously been investigated, this is the first study to reveal the inhibitory activity of C. sappan extract on PRRSV replication in MARC-145 cells.
Regarding phytochemical content, C. sappan extract had the highest total phenolic content $(220.52 \pm 4.47$ $\mathrm{mM}$ GAE/g sample). The total phenolic content of a plant is considered an indicator of its antioxidant capacity because the redox properties of phenolic compounds allow them to act as reducing agents, hydrogen donors, and radical scavengers [22]. Previously, Lee et al. [26] reported that ethanolic C. sappan extract had a total phenolic content of $723.67 \mu \mathrm{g}$ GAE/mg. The values of total phenolic content in this study were slightly 

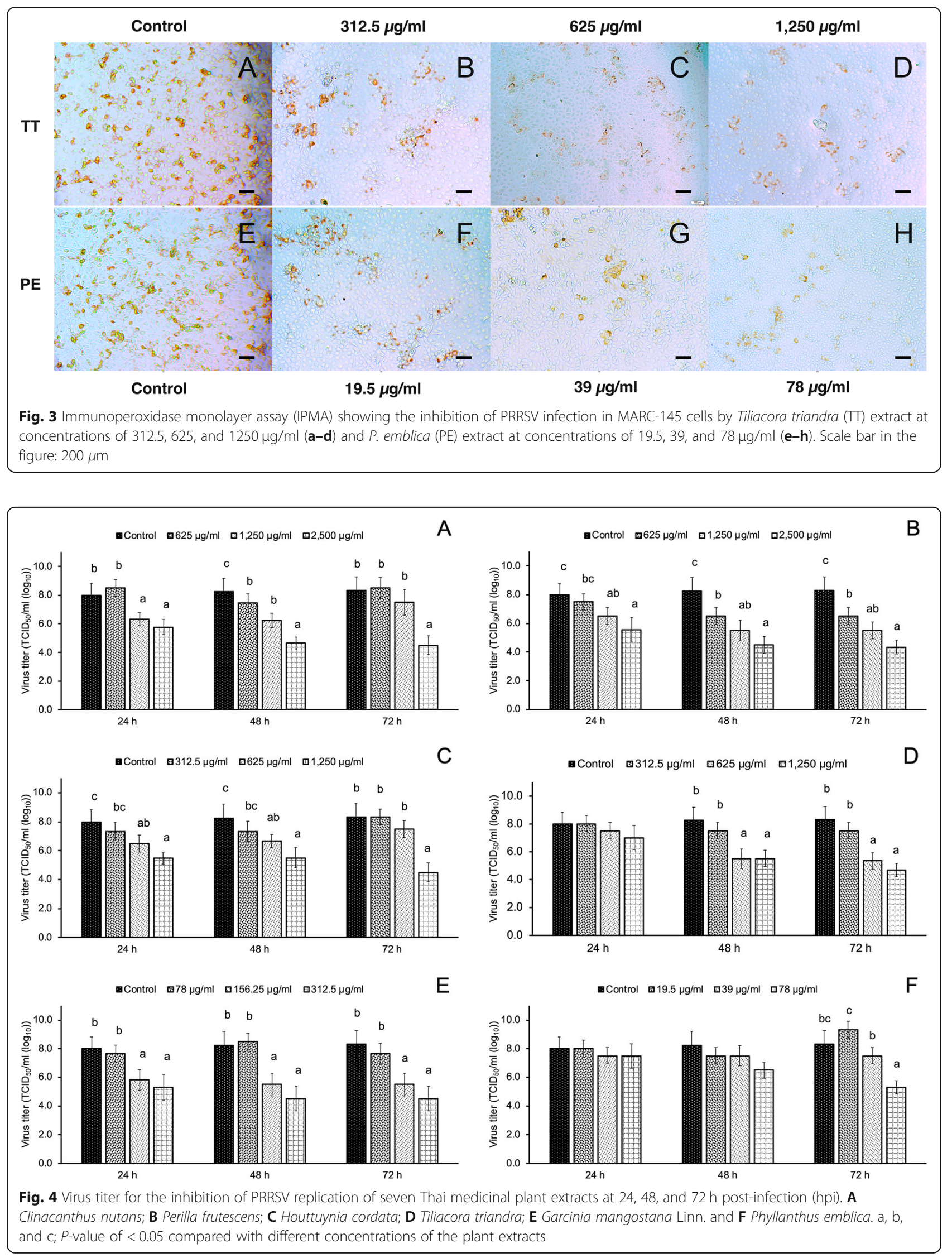

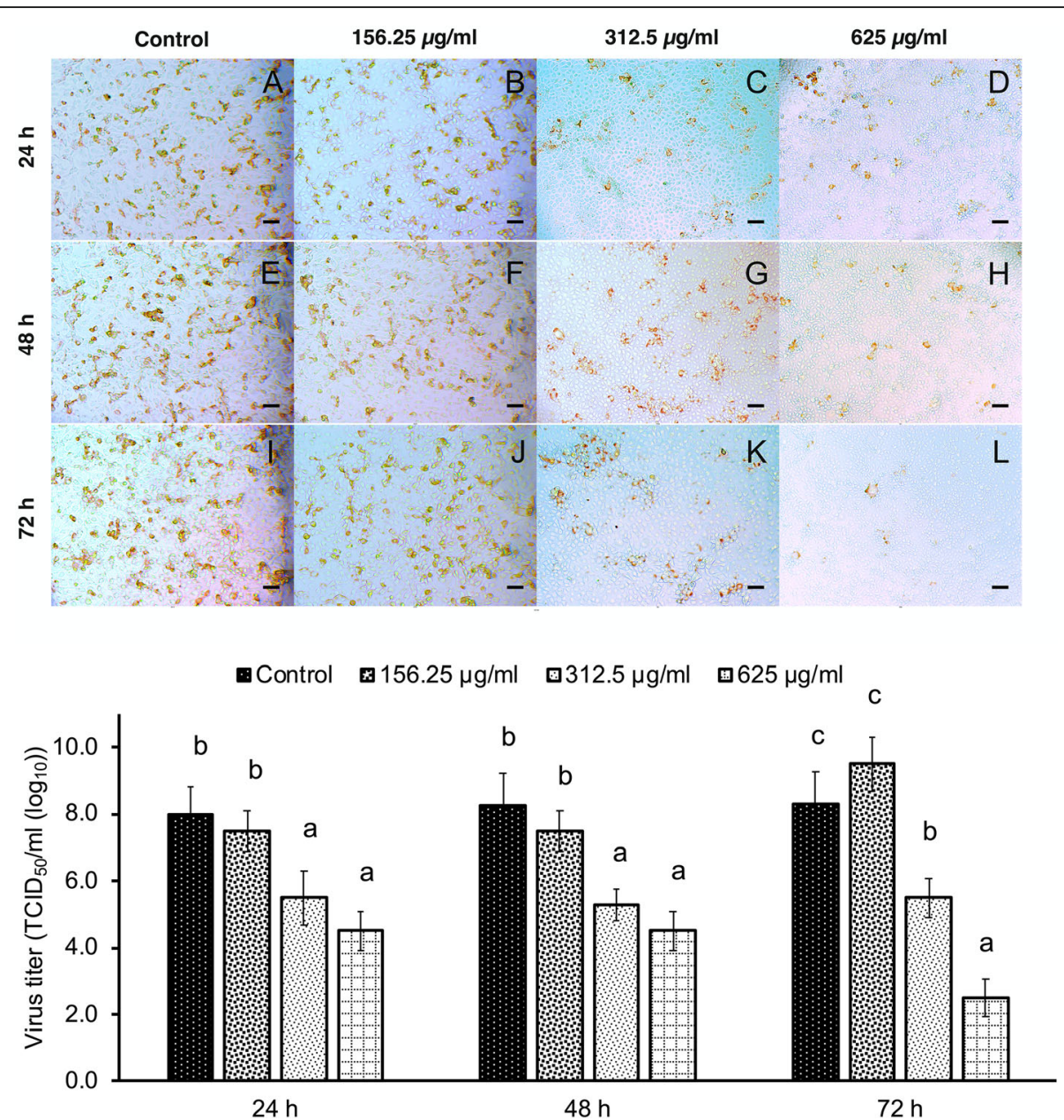

Fig. 5 IPMA of Caesalpinia sappan Linn. inhibiting PRRSV replication in MARC-145 cells at 24 (A-D), 48 (E and $\mathbf{F}$ ), and $72 \mathrm{~h}$ post-infection (hpi) (I-L). a, b, and C: P-value of < 0.05 compared with different concentrations of C. sappan. Scale bar in the figure: $200 \mu \mathrm{m}$

different from those reported previously. This may be because of the different durations, geographical variations, or extraction methods, which may have altered the phenolic content. Ethanolic plant extracts can be used for the investigation of antiviral activity in a cell line.
Abu-Jafar and Huleihel [27] reported that ethanolic Eucalyptus camaldulensis leave extracts had strong antiviral activity against different members of the herpes virus family (HSV-1, HSV-2, and VZV). Ramalingam et al. [28] reported that the ethanolic extracts of Andrographis paniculata have

Table 1 Total phenolic contents and antioxidant activities of seven Thai medicinal plant extracts

\begin{tabular}{lllll}
\hline & $\begin{array}{l}\text { Total phenolic } \\
(\mathrm{mM} \mathrm{GAE} / \mathrm{g})\end{array}$ & $\begin{array}{l}\text { DPPH } \\
\left(\mathrm{I} \mathrm{C}_{50}, \mathrm{mg} / \mathrm{ml}\right)\end{array}$ & $\begin{array}{l}\text { ABTS } \\
\left(\mathrm{IC} \mathrm{C}_{50}, \mathrm{mg} / \mathrm{ml}\right)\end{array}$ & $\begin{array}{l}\text { FRAP } \\
\left(\mathrm{mM} \mathrm{Fe} \mathrm{F}^{2+} / \mathrm{g}\right)\end{array}$ \\
\hline Caesalpinia sappan & $220.52 \pm 4.47$ & $1.17 \pm 0.06$ & $2.57 \pm 0.16$ & $334.78 \pm 13.15$ \\
Garcinia mangostana & $91.16 \pm 4.62$ & $4.82 \pm 0.58$ & $4.98 \pm 0.10$ & $46.12 \pm 1.27$ \\
Houttuynia cordata & $14.25 \pm 0.20$ & $97.79 \pm 4.14$ & $72.02 \pm 4.01$ & $8.55 \pm 0.18$ \\
Perilla frutescens & $29.86 \pm 0.41$ & $11.68 \pm 0.51$ & $21.37 \pm 1.28$ & $43.32 \pm 0.92$ \\
Clinacanthus nutans & $25.52 \pm 0.22$ & $50.34 \pm 5.60$ & $37.82 \pm 1.25$ & $18.39 \pm 0.54$ \\
Phyllanthus emblica & $44.35 \pm 0.24$ & $3.49 \pm 0.17$ & $4.95 \pm 0.11$ & $94.17 \pm 0.62$ \\
Tiliacora triandra & $30.45 \pm 1.51$ & $17.77 \pm 0.22$ & $21.16 \pm 1.06$ & $30.58 \pm 1.13$ \\
\hline
\end{tabular}

DPPH 2,2-diphenyl-1-picrylhydrazyl, ABTS 2,2-azino-bis (3-ethylbenzothiazo-line-6-sulfonic acid) diammonium salt, FRAP ferric reducing antioxidant power, GAE gallic acid equivalents, $I_{50}$ half maximal inhibitory concentration 
the highest antiviral inhibitory effects against dengue virus in Vero cells.

The screening of plants as possible sources of antiviral agents has led to the discovery of potent inhibitors of in vitro viral replication, thereby increasing the probability of identifying new bioactive plant compounds [29]. These findings suggest the appropriate species and concentration of plant extract that could effectively inhibit PRRSV replication, with both $T$. triandra and C. sappan extracts being highly effective in inhibiting PRRSV infection in vitro by interfering with viral attachment and inhibiting viral replication and/or virus release, respectively. The modes of action of $T$. triandra and $C$. sappan extracts against PPRSV require further investigation but are likely to be related to the natural compounds they contain. Therefore, it was speculated that both T. trian$d r a$ and C. sappan extracts are potential candidates for preventing PRRSV infection in pigs. However, the plant extracts used for testing antiviral activity was crude extracts. In future, we plan to purify the most effective Thai medicinal plant extracts (T. triandra and C. sappan extracts) for screening the active compound that is highly effective against PRRSV.

\section{Conclusion}

Thai medicinal plant extracts exhibit antiviral activity against PRRSV. T. triandra extract effectively inhibited PRRSV infection. and C. sappan extract had the strongest antiviral activity against PRRSV replication. These activities can be presumably attributed to the total phenolic contents and antioxidant activities of these plant extracts. Although several previous studies have shown the antiviral activity of plant extracts against PRRSV, there are no reports on the antiviral activities of $T$. triandra and C. sappan extracts against PRRSV. To the best of our knowledge, this study is the first to report the inhibitory activity of $T$. triandra and $C$. sappan extracts against PRRSV activity in vitro. Further studies are required to elucidate the mechanisms of action of these plant extracts on PRRSV.

\section{Methods}

\section{Chemicals}

All chemicals used in this study were of analytical grade or higher. Ethanol and methanol were obtained from Merck (Darmstadt, Germany). ABTS, 6-hydroxy-2,5,7,8tetramethylchroman-2-carboxylic acid (Trolox), DPPH, Folin-Ciocalteu phenol reagent, 3-(4,5-dimethylthiazol2-yl)-2,5-diphenyl tetrazolium bromide (MTT), sodium carbonate, and 2,4,6-tri-pyridyl-s-triazine were purchased from Sigma Chemical Co. (St. Louis, MO, USA). Ferric chloride hexahydrate and potassium persulfate were procured from LOBA CHEMIE PVT (Mumbai, India). Gallic acid was procured from Fluka Chemical
Co. (Buchs, Switzerland). Dulbecco's modified Eagle's medium (DMEM) was procured from Gibco (Massachusetts, USA).

\section{Plant extracts, cells, and viruses}

Ethanolic C. sappan, G. mangostana, H. cordata, P. frutescens, $C$. nutans, $P$. emblica, and $T$. triandra extracts were purchased from Specialty Natural Product Co. Ltd. (Thailand).

MARC-145 tissue culture cells were grown in DMEM containing $10 \%$ fetal bovine serum (Gibco) and $1 \%$ penicillin/streptomycin and incubated at $37^{\circ} \mathrm{C}$ in a $5 \% \mathrm{CO}_{2}$ atmosphere. To produce inoculated cells, PRRSV (VR2332 North American genotype) was propagated in MARC-145 cells, and virus titer was quantified using IPMA.

\section{Cytotoxicity assay}

The cytotoxicity of the seven Thai medicinal plant extracts was determined using the MTT assay. Briefly, MARC-145 cells were plated at a density of 5000 cells/ well in 96-well plates and incubated in a $5 \% \mathrm{CO}_{2}$ atmosphere at $37{ }^{\circ} \mathrm{C}$ for $24 \mathrm{~h}$. When cells had at least $90 \%$ confluence, the medium was removed and replaced with medium containing two-fold serial dilutions of the plant extracts. In addition, medium without plant extract was used as a positive control. Incubation was then continued in a $5 \% \mathrm{CO}_{2}$ atmosphere at $37^{\circ} \mathrm{C}$ for $72 \mathrm{~h}$. After this, the medium was removed, $20 \mu \mathrm{l}$ of freshly prepared MTT solution $(5 \mathrm{mg} / \mathrm{ml})$ was added to each well, and the plates were incubated at $37^{\circ} \mathrm{C}$ for $4 \mathrm{~h}$. Then, the medium was replaced with $150 \mu \mathrm{L}$ DMSO to dissolve the crystals, and the plates were incubated at $37^{\circ} \mathrm{C}$ for $5 \mathrm{~min}$ to dissolve any air bubbles before measuring the MTT signal at an absorbance of $550 \mathrm{~nm}$. Results are reported as $\mathrm{CC}_{50}$.

\section{Inhibition of virus infection assay}

The inhibition of virus infection assay was performed as previously described [12]. Briefly, the plant extracts at the concentration that was determined in the cytotoxicity test outlined above and at two lower concentrations in two-fold dilution were mixed with PRRSV at $10^{8}$ $\mathrm{TCID}_{50} / \mathrm{ml}$ at a ratio of $1: 1$ and incubated at $37^{\circ} \mathrm{C}$ for 1 h. DMSO (1\%) containing medium mixed with PRRSV served as the control. Thereafter, the mixture of PRRSV and plant extracts as well as controls were inoculated in MARC-145 cells at a density of 5000 cells/well in a 96well plate and incubated at $37^{\circ} \mathrm{C}$ for $1 \mathrm{~h}$. Subsequently, the medium was removed and replaced with a fresh medium containing 10\% FBS. The plates with MARC145 cells were cultured under standard conditions for $24 \mathrm{~h} \mathrm{hpi}$, and supernatants were collected to quantify virus titer. 


\section{Inhibition of viral replication assay}

The inhibition of viral replication assay was performed as previously described [12]. Briefly, MARC-145 cells were plated at a density of 5000 cells/well in 96-well plates and infected with PRRSV at a multiplicity of infection of 1 at $37^{\circ} \mathrm{C}$ for $1 \mathrm{~h}$. Then, PRRSV was removed from each well and replaced with the diluted plant extracts at the concentration that was determined in the cytotoxicity test and at two lower concentrations ins two-fold dilution. Further, $1 \%$ DMSO was mixed to medium as the control. The plates were cultured under standard conditions; supernatants were collected at 24 , 48 , and $72 \mathrm{hpi}$; and virus titer was quantified.

\section{Virus titer}

Virus titer was further assessed by IPMA as previously described [30]. Briefly, cells were fixed with $100 \mu \mathrm{l}$ of $4 \%$ cold formalin for $15 \mathrm{~min}$ at room temperature (RT), washed once with $100 \mu \mathrm{l}$ of phosphate-buffered saline (PBS) and twice with $100 \mu \mathrm{l}$ of $0.5 \%$ PBS Tween-20 (PBST), and blocked with $100 \mu \mathrm{l}$ of $1 \%$ BSA in $0.5 \%$ PBST for $30 \mathrm{~min}$ at RT. After blocking, the cells were stained with $70 \mu \mathrm{l}$ of anti-PRRSV NC protein monoclonal antibody (Median Diagnostics, Gangwon-do, Korea) diluted at a ratio of 1:400 at RT for $60 \mathrm{~min}$, washed, and incubated with peroxidase-conjugated AffiniPure Goat Anti-Mouse IgG $(\mathrm{H}+\mathrm{L})$ (Jackson ImmunoResearch, Pennsylvania, USA) diluted at a ratio of 1:1200 for 60 min at RT. After washing thrice with PBS, the cells were counter stained with 1,5-diaminopentane substrate and examined under a microscope. Virus titer is expressed as $\mathrm{TCID}_{50}$ and was determined using the Reed-Muench method.

\section{Phytochemical analysis}

The total phenolic contents of the plant extracts were determined using the Folin-Ciocalteu method [31], and their free radical-scavenging activities were determined using the DPPH-scavenging and ABTS-scavenging assays, as previously reported [32, 33]. Antioxidant activities were determined using the FRAP assay, according to the Benzie and Strain method [34].

\section{Statistical analysis}

Differences in antiviral activities among the different concentrations of each plant extract were tested using one-way analysis of variance with Tukey's post hoc test for a comparison of means. $\mathrm{CC}_{50}$ was calculated using regression analysis of dose-response curves for the MTT assay. All statistical analyses were performed using the SPSS 23.0 software (SPSS Inc., Chicago, IL, USA) with a significance level of $P$-value of $\leq 0.05$.

\section{Abbreviations}

PRRS: Porcine reproductive and respiratory syndrome; PRRSV: Porcine reproductive and respiratory syndrome virus; $\mathrm{TCID}_{50}$ : Median tissue culture infective dose; RNA: Ribonucleic acid; hpi: Hour post-infection; CC $_{50}$ : 50\% cytotoxic concentration; IPMA: Immunoperoxidase monolayer assay; GAE: Gallic acid equivalent; DPPH: 2, 2-diphenyl-1-picrylhydrazyl; ABTS: 2, 2azino-bis(3-ethylbenzothiazo-line-6-sulfonic acid) diammonium salt; FRAP: Ferric-reducing antioxidant power; $I_{50}$ : Half-maximal inhibitory concentration; DMEM: Dulbecco's Modified Eagle Medium; MTT: 3-(4,5dimethylthiazol-2-yl)-2,5-diphenyl tetrazolium bromide; $\mathrm{CO}_{2}$ : Carbon dioxide; DMSO: Dimethyl sulfoxide; FBS: Fetal bovine serum; PBS: Phosphate-buffered saline; RT: Room temperature

\section{Acknowledgments}

The authors thank Dr. Wolfram Spreer of the University of Hohenheim for his critical comments on this article and thank Enago (https://www.enago.com) for the English language review.

\section{Authors' contributions}

$\mathrm{KP}, \mathrm{SH}$, and $\mathrm{KS}$ contributed to the study design. CA performed the experiments, carried out the statistical analysis, and drafted the manuscript. $\mathrm{KP}, \mathrm{SH}$ and $\mathrm{KS}$ contributed to the statistical analysis and critically reviewed the manuscript. KP, MS, SM, WR, and KS conceived the study, coordinated the work described, and contributed to the manuscript preparation. All authors read and approved the final manuscript.

\section{Funding}

CA was supported financially by a Ph.D. scholarship of Research and Researcher for Industries Projects (RRi), Thailand Science Research and Innovation, under contract no. PHD6110042. The funders had no role in study design, data collection, and interpretation, or the decision to submit the work for publication. Also, this project was partially supported by Chiang Mai University.

\section{Availability of data and materials}

The datasets supporting the results of this article are available in the figshere (https://figshare.com/s/97bfdb8d693a8c95ffaf).

Ethics approval and consent to participate

Not applicable.

\section{Consent for publication}

Not applicable.

\section{Competing interests}

The authors declare that they have no competing interests.

\section{Author details}

${ }^{1}$ Department of Animal and Aquatic Sciences, Faculty of Agriculture, Chiang Mai University, 239, Huaykaew Road, Suthep, Muang, Chiang Mai 50200, Thailand. 'Department of Veterinary Bioscience and Veterinary Public Health, Faculty of Veterinary Medicine, Chiang Mai University, Chiang Mai 50100, Thailand. ${ }^{3}$ Cluster of Research and Development of Pharmaceutical and Natural Products Innovation for Human or Animal, Chiang Mai University, Chiang Mai 50200, Thailand. "Environment and Health Research Unit, Research Institute for Health Sciences, Chiang Mai University, Chiang Mai 50200, Thailand. ${ }^{5}$ Department of Pharmaceutical Sciences, Faculty of Pharmacy, Chiang Mai University, Chiang Mai 50200, Thailand.

Received: 29 November 2019 Accepted: 17 March 2020

Published online: 30 March 2020

\section{References}

1. Zhang Q, Yoo D. PRRS virus receptors and their role for pathogenesis. Vet Microbiol. 2015;177:229-41. https://doi.org/10.1016/j.vetmic.2015.04.002.

2. Lunney JK, Fang Y, Ladinig A, Chen N, Li Y, Rowland B, et al. Porcine reproductive and respiratory syndrome virus (PRRSV): pathogenesis and interaction with the immune system. Annu Rev Anim Biosci. 2016;4:129-54. https://doi.org/10.1146/annurev-animal-022114-111025. 
3. Nilubol D, Tripipat T, Hoonsuwan T, Kortheerakul K. Porcine reproductive and respiratory syndrome virus, Thailand, 2010-2011. Emerg Infect Dis. 2012; 18:2039-43. https://doi.org/10.3201/eid1811.111105.

4. Benfield DA, Nelson E, Collins JE, Harris L, Goyal SM, Robison D, et al. Characterization of swine infertility and respiratory syndrome (SIRS) virus (isolate ATCC VR-2332). J Vet Diagnostic Investig. 1992;4:127-33. https://doi. org/10.1177/104063879200400202.

5. Pu X, Liang J, Shang R, Wang X, Wang Z, Hua L, et al. Influence of Hypericum perforatum extract on piglet infected with porcine respiratory and reproductive syndrome virus. Agric Sci China. 2009;8:730-9. https://doi. org/10.1016/S1671-2927(08)60272-2

6. Albina E. Epidemiology of porcine reproductive and respiratory syndrome (PRRS): an overview. Vet Microbiol. 1997;55:309-16 https://doi.org/10.1016/ S0378-1135(96)01322-3.

7. Thanapongtharm W, Linard C, Pamaranon N, Kawkalong S, Noimoh T, Chanachai $\mathrm{K}$, et al. Spatial epidemiology of porcine reproductive and respiratory syndrome in Thailand. BMC Vet Res. 2014;10:174. https://doi.org/ 10.1186/s12917-014-0174-y.

8. Damrongwatanapok S, Arsayuth K, Kongkrong C, Parchariyanon S, Pinyochon WTU. Serological studies and isolation of porcine reproductive and respiratory syndrome (PRRS) virus in Thailand. J Thai Vet Med Assoc. 1996:47:19-30

9. Labarque G, Van Gucht S, Van Reeth K, Nauwynck H, Pensaert M. Respiratory tract protection upon challenge of pigs vaccinated with attenuated porcine reproductive and respiratory syndrome virus vaccines. Vet Microbiol. 2003; 95:187-97 https://doi.org/10.1016/S0378-1135(03)00157-3.

10. Anantikulchai $P$, Emprom $P$, Pringproa K, Yamsakul P. In vitro Cytotoxicity Test and Antiviral Activity of Curcuminoids from Turmeric Extract Against PRRS Virus. Vet Integr Sci. 2017;15:199-205. https://doi.org/10.14456/cmvj.2017.X.

11. Gao L, Zhang W, Sun Y, Yang Q, Ren J, Liu J, et al. Cryptoporus volvatus extract inhibits porcine reproductive and respiratory syndrome virus (PRRSV) in vitro and in vivo. PLoS One. 2013;8:e63767. https://doi.org/10.1371/ journal.pone.0063767.

12. Pringproa K, Khonghiran O, Kunanoppadol S. In Vitro Virucidal and Virustatic Properties of the Crude Extract of Cynodon dactylon against Porcine Reproductive and Respiratory Syndrome Virus In Vitro Virucidal and Virustatic Properties of the Crude Extract of Cynodon dactylon against Porcine Reprodu. Vet Med Int. 2014;2014:947589. https://doi.org/10.1155/ 2014/947589.

13. Liu A, Shu S, Qin H, Ming S, Lee Y, Wang Y, et al. In vitro anti-influenza viral activities of constituents from Caesalpinia sappan. Planta Med. 2009;75:3379. https://doi.org/10.1055/s-0028-1112208 Epub 2009 Jan 15.

14. Chen S-X. Min wan B-NL. Active constituents against HIV-1 protease from Garcinia mangostana. Planta Med. 1996;62:381-2. https://doi.org/10.1055/s2006-957916.

15. Chiow KH, Phoon MC, Putti T, Tan BKH, Chow VT. Evaluation of antiviral activities of Houttuynia cordata Thunb. Extract, quercetin, quercetrin and cinanserin on murine coronavirus and dengue virus infection. Asian Pac J Trop Med. 2016;9:1-7 https://doi.org/10.1016/j.apjtm.2015.12.002.

16. Kawahata T, Otake T, Mori H, Kojima Y, Oishi I, Oka S, et al. A novel substance purified from Perilla Frutescens Britton inhibits an early stage of HIV-1 replication without blocking viral adsorption. Antivir Chem Chemother. 2002;13:283-8. https://doi.org/10.1177/095632020201300503.

17. Haetrakul T, Dunbar SG, Chansue N. Antiviral activities of Clinacanthus nutans (Burm.F.) Lindau extract against cyprinid herpesvirus 3 in koi (Cyprinus carpio koi). J Fish Dis. 2018;41:581-7. https://doi.org/10.1111/jfd.12757.

18. Xiang Y, Pei Y, Qu C, Lai Z, Ren Z, Yang K, et al. In vitro anti-herpes simplex virus activity of 1,2,4,6-tetra-O-galloyl- $\beta$-d-glucose from Phyllanthus emblica L. (Euphorbiaceae). Phyther Res. 2011;25:975-82. https://doi.org/10.1002/ptr.3368.

19. Feng J, Bai X, Cui T, Zhou H, Chen Y, Xie J, et al. In vitro antiviral activity of Germacrone against porcine reproductive and respiratory syndrome virus. Curr Microbiol. 2016;73:317-23. https://doi.org/10.1007/s00284-016-1042-8.

20. Mehrbod P, Abdalla MA, Njoya EM, Ahmed AS, Fotouhi F, Farahmand B, et al. South African medicinal plant extracts active against influenza a virus. BMC Complement Altern Med. 2018;18:112. https:/doi.org/10.1186/s12906-018-2184-y.

21. Adnan A, Allaudin ZN, Hani H, Loh H-S, Khoo T-J, Ting KN, et al. Virucidal activity of Garcinia panvifolia leaf extracts in animal cell culture. BMC Complement Altern Med. 2019;19:169. https//doi.org/10.1186/s12906-019-2586-5.

22. Weerawatanakorn M, Rojsuntornkitti K, Pan M-H, Wongwaiwech D. Some Phytochemicals and Anti-inflammation Effect of Juice from Tiliacora triandra Leaves. J Food Nutr Res. 2018;6:32-8. https://doi.org/10.12691/jfnr-6-1-6.
23. Rattana S, Cushnie B, Taepongsorat L, Phadungkit M. Chemical constituents and in vitro anticancer activity of Tiliacora triandra leaves. Pharmacogn J. 2016;8. https://doi.org/10.5530/pj.2016.1.1.

24. Sureram S, Senadeera SPD, Hongmanee P, Mahidol C, Ruchirawat S, Kittakoop P. Antimycobacterial activity of bisbenzylisoquinoline alkaloids from Tiliacora triandra against multidrug-resistant isolates of mycobacterium tuberculosis. Bioorg Med Chem Lett. 2012;22:2902-5 https://doi.org/10. 1016/j.bmcl.2012.02.053.

25. Srinivasan R, Selvam GG, Karthik S, Mathivanan K, Baskaran R, Karthikeyan M, et al. in vitro antimicrobial activity of Caesalpinia sappan L. Asian Pac J Trop Biomed 2012;2:S136-S139. doi:https://doi.org/10.1016/S2221-1691(12)60144-0.

26. Lee M-J, Lee H-S, Kim H, Yi H-S, Park S-D, Moon H-I, et al. RETRACTED: antioxidant properties of benzylchroman derivatives from Caesalpinia sappan L. against oxidative stress evaluated in vitro. J Enzyme Inhib Med Chem. 2010;25:608-14. https://doi.org/10.3109/14756360903373376.

27. Abu-jafar A, Huleihel M. Antiviral activity of Eucalyptus camaldulensis leaves ethanolic extract on herpes viruses infection. Int J Clin Virol. 2017;1:001-9. https://doi.org/10.29328/journal.ijcv.1001001.

28. Ramalingam S, Karupannan S, Padmanaban P, Vijayan S, Sheriff K, Palani G, et al. Anti-dengue activity of Andrographis paniculata extracts and quantification of dengue viral inhibition by SYBR green reverse transcription polymerase chain reaction. Ayu. 2018;39:87-91. https://doi.org/10.4103/ayu. AYU_144_17.

29. Kohn LK, Foglio MA, Rodrigues RA. Sousa IM de O, martini MC, Padilla MA Lima Neto DF de AC. In-vitro antiviral activities of extracts of plants of the Brazilian Cerrado against the avian Metapneumovirus (aMPV). Brazilian J Poult Sci. 2015;17:275-80 https://doi.org/10.1590/1516-635X1703275-280.

30. Zhang J, Liu W, Chen W, Li C, Xie M, Bu Z. Development of an Immunoperoxidase Monolayer Assay for the Detection of Antibodies against Peste des Petits Ruminants Virus Based on BHK-21 Cell Line Stably Expressing the Goat Signaling Lymphocyte Activation Molecule; 2016. p. 1-14.

31. Slinkard K, Singleton VL. Total phenol analysis: automation ans comparison with manual methods. Am J Enol Vitic. 1977;28:49-55 http://www. ajevonline.org/content/28/1/49.

32. Brand-Williams W, Cuvelier ME, Berset C. Use of a free radical method to evaluate antioxidant activity. LWT - Food Sci Technol. 1995;28:25-30 https:// doi.org/10.1016/S0023-6438(95)80008-5.

33. Binsan W, Benjakul S, Visessanguan W, Roytrakul S, Tanaka M, Kishimura H. Antioxidative activity of Mungoong, an extract paste, from the cephalothorax of white shrimp (Litopenaeus vannamei). Food Chem. 2008; 106:185-93 https://doi.org/10.1016/j.foodchem.2007.05.065.

34. Benzie IFF, Strain JJBT-M in E. Ferric reducing/antioxidant power assay: Direct measure of total antioxidant activity of biological fluids and modified version for simultaneous measurement of total antioxidant power and ascorbic acid concentration. In: Oxidants and Antioxidants Part A: Academic; 1999. p. 15-27. https://doi.org/10.1016/S0076-6879(99)99005-5.

\section{Publisher's Note}

Springer Nature remains neutral with regard to jurisdictional claims in published maps and institutional affiliations.

Ready to submit your research? Choose BMC and benefit from:

- fast, convenient online submission

- thorough peer review by experienced researchers in your field

- rapid publication on acceptance

- support for research data, including large and complex data types

- gold Open Access which fosters wider collaboration and increased citations

- maximum visibility for your research: over $100 \mathrm{M}$ website views per year

At BMC, research is always in progress.

Learn more biomedcentral.com/submissions 